University of South Florida

DIGITAL COMMONS

Digital Commons @ University of

@ UNIVERSITY OF SOUTH FLORIDA

South Florida

School of Geosciences Faculty and Staff

Publications

School of Geosciences

$9-2007$

\title{
Variable Intensity of Teleconnections during the Late Holocene in Subtropical North America from an Isotopic Study of Speleothem from Florida
}

\author{
Philip E. van Beynen \\ University of South Florida, vanbeyne@usf.edu \\ Yemane Asmerom \\ University of New Mexico, asmerom@unm.edu \\ Victor J. Polyak \\ University of New Mexico, polyak@unm.edu \\ Limaris R. Soto \\ University of South Florida \\ Jason S. Polk \\ University of South Florida
}

Follow this and additional works at: https://digitalcommons.usf.edu/geo_facpub

Part of the Earth Sciences Commons

\section{Scholar Commons Citation \\ van Beynen, Philip E.; Asmerom, Yemane; Polyak, Victor J.; Soto, Limaris R.; and Polk, Jason S., "Variable Intensity of Teleconnections during the Late Holocene in Subtropical North America from an Isotopic Study of Speleothem from Florida" (2007). School of Geosciences Faculty and Staff Publications. 2073. https://digitalcommons.usf.edu/geo_facpub/2073}

This Article is brought to you for free and open access by the School of Geosciences at Digital Commons @ University of South Florida. It has been accepted for inclusion in School of Geosciences Faculty and Staff Publications by an authorized administrator of Digital Commons @ University of South Florida. For more information, please contact digitalcommons@usf.edu. 


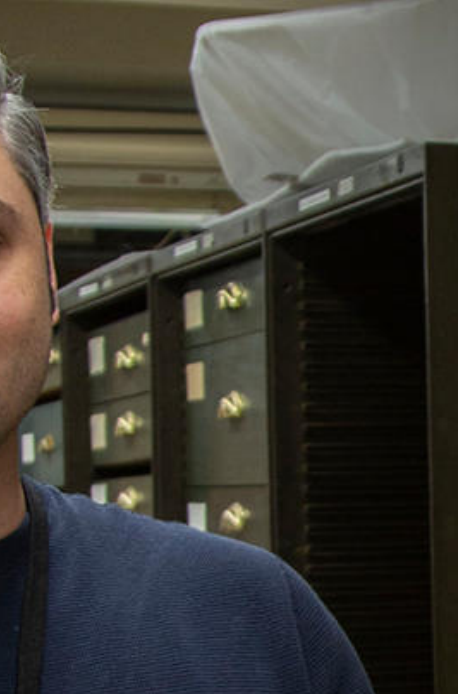

"The more opportunities there are to get students involved, the more you will encourage previously unreached and unrepresented groups to join the Earth and Space science community."

Ryan Haupt Research Fellow, Smithsonian Museum of Natural History 2015 Student Travel

Grant Recipient

Support the next generation of Earth and space scientists. Donate to the Austin Student Travel Grant Challenge.

\section{ASU100}

agu.org/austin | \#AGU100 


\title{
Variable intensity of teleconnections during the late Holocene in subtropical North America from an isotopic study of speleothem from Florida
}

\author{
Philip E. van Beynen, ${ }^{1}$ Yemane Asmerom, ${ }^{2}$ Victor Polyak, ${ }^{2}$ Limaris Soto, ${ }^{3}$ \\ and Jason S. Polk ${ }^{1}$ \\ Received 19 June 2007; revised 8 August 2007; accepted 9 August 2007; published 22 September 2007.
}

[1] The persistence and influence of both tropical and extratropical teleconnections on the hydrology of subtropical North America are little understood. Major atmosphericoceanic controls on the isotopic composition of the precipitation reconstructed from a 1,000 year old stalagmite are the North Atlantic Oscillation (NAO) and the Pacific Decadal Oscillation (PDO). These teleconnections create decadal- to centennial-scale changes in the seasonal distribution of precipitation. An increase in the winter proportion of annual precipitation coincides with negative phase NAO conditions and a positive phase PDO. However, the PDO's influence appears to be weakened when it is out of phase with the El Niño Southern Oscillation (ENSO). The $\mathrm{NAO}$ exerts the greater decadal influence on this regions climate than the El Niño Southern Oscillation (ENSO), suggesting a greater significance of high latitude controls on subtropical North America. Citation: van Beynen, P. E., Y. Asmerom, V. Polyak, L. Soto, and J. S. Polk (2007), Variable intensity of teleconnections during the late Holocene in subtropical North America from an isotopic study of speleothem from Florida, Geophys. Res. Lett., 34, L18703, doi:10.1029/2007GL031046.

\section{Introduction}

[2] Connections between the high latitude and tropical climate change must pass through the subtropical latitudes In the modern climate regime there is a strong linkage between short-term (sub-annual to decadal) subtropical North American climate and tropical (ENSO) and extratropical (NAO or PDO) climate modulators [Enfield et al., 2001; Hardy and Henderson, 2003; Hagemeyer, 2006].

[3] While strong connections exist between the Pacific and North Atlantic Oceans (PDO, NAO and ENSO) and the modern subtropical climate of North America [Hagemeyer, 2006], their direct influence has been shown for only the last 50 years. The persistence of this climate linkage and controls on long-term climate variability of sub-tropical North American climate are not well understood due to the lack of proxies with high resolution absolute chronology. Speleothem calcite can record changes in precipitation,

\footnotetext{
${ }^{1}$ Department of Geography, University of South Florida, Tampa, Florida, USA.

${ }^{2}$ Department of Earth and Planetary Sciences, University of New Mexico, Albuquerque, New Mexico, USA.

${ }^{3}$ Department of Geology, University of South Florida, Tampa, Florida, USA.

Copyright 2007 by the American Geophysical Union. 0094-8276/07/2007GL031046
}

reflected in variations in oxygen isotopes [Burns et al., 2002; Fleitmann et al., 2003; Lachniet et al., 2004; Polyak et al., 2004]. Moreover, the material can be precisely dated using uranium-series disequilibrium [Li et al., 1989; Dorale et al., 1992]. Here we present precipitation proxy data for the past 1000 years based on the changes in oxygen isotope composition of Floridian speleothem calcite.

\section{Interpretation of Isotopic Record}

[4] An actively depositing stalagmite was collected from Briars Cave near the town of Ocala in central Florida. Uranium series disequilibrium dating using inductive coupled plasma mass spectrometry $\left({ }^{234} \mathrm{U}^{230} \mathrm{Th}\right)$ created the chronology for the oxygen isotopes data (Table $\mathrm{S} 1^{1}$ ). Nine calcite samples $(90-150 \mathrm{mg})$ were extracted for this chronology. Errors associated with dates (reported as $2 \sigma$ ) very small ranging between 29-57 years and none overlap in time. All the dates were in chronological order (Figure 1a), with the exception of the age at $1284 \mathrm{yr}$ BP (BP is before present, i.e. $0 \mathrm{yr} \mathrm{BP}$ is calendar $\mathrm{yr} 2007)$. This one erroneous age (1284 $\pm 57 \mathrm{yr} \mathrm{BP})$ has an anomalously high U-series age probably due to increased initial ${ }^{230} \mathrm{Th}$ from water inclusions, which are seen in petrographic study of sample (see auxiliary materials for more petrograhic information on the speleothem). A sixth-order polynomial equation $\left(\mathrm{r}^{2}=0.99\right)$ was used to create the age model (Figure 1a) for the speleothem oxygen isotopic values (Figure 1b).

[5] The two major possible contributors to the $\delta^{18} \mathrm{O}$ signal in the Briars speleothem are temperature dependence of the water-calcite isotope fractionation and the isotopic composition of the seepage (rainfall) water. The range of the $\delta^{18} \mathrm{O}$ values is approximately $1.5 \%$ (Figure $1 \mathrm{~b}$ ) which would require temperature change of $>6^{\circ} \mathrm{C}$ during deposition, far beyond any value found in the literature for this time interval or locale. A more viable explanation is changes in the isotopic composition of precipitation, with clear seasonal differences of $\sim 0.9 \%$ between summer (enriched in ${ }^{18} \mathrm{O}$, mean value of $-2.39 \%$ ) and winter (depleted in ${ }^{18} \mathrm{O}$, mean value of $-3.28 \%$ ) rainfall as shown in a recent study for central Florida [Sacks, 2002; K. Pace-Graczyk, unpublished data, 2007] Such seasonal differences of $\delta^{18} \mathrm{O}$ values of precipitation are produced due to variable seasonal convection. Large summer thunderstorms experience enhanced convection, leading to rain

\footnotetext{
${ }^{1}$ Auxiliary material data sets are available at ftp://ftp.agu.org/apend/gl/ 2007gl031046. Other auxiliary material files are in the HTML.
} 

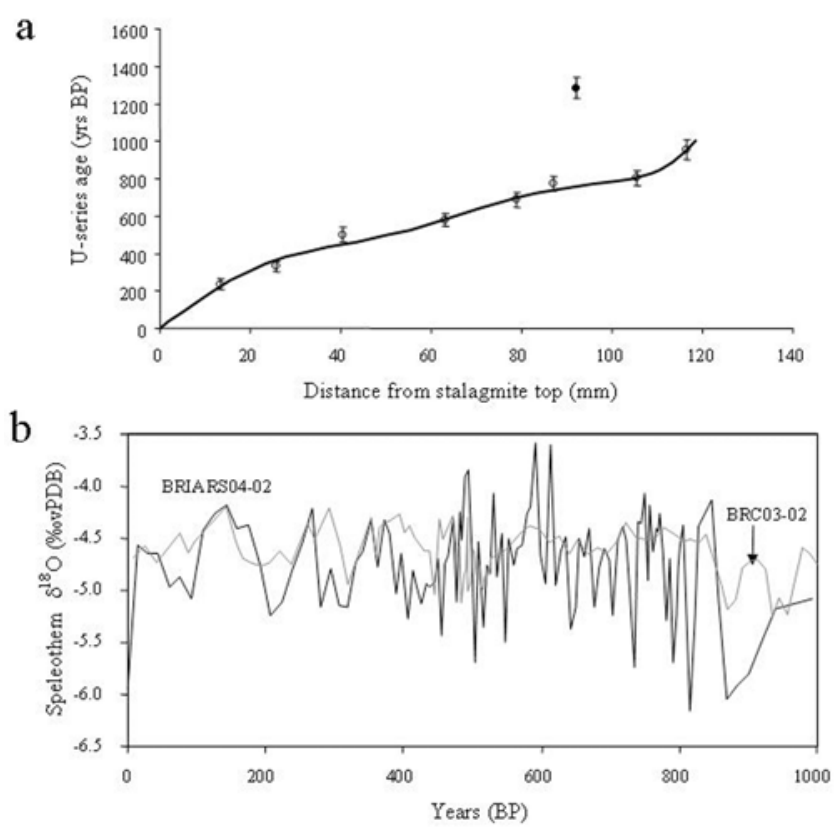

Figure 1. (a) U-series age model for the stalagmite from Briars Cave (BRIARS04-02 $\delta^{18} \mathrm{O}$ ), FL, and (b) Comparison between BRIARS04-02 and BRC03-02 $\delta^{18} \mathrm{O}$ records.

forming at lower temperatures, resulting in depletion of ${ }^{18} \mathrm{O}$ in the precipitation. Conversely, reduced convection during winter frontal systems produces precipitation more enriched in ${ }^{18} \mathrm{O}$. Changes in the seasonal distribution of precipitation would affect the isotopic composition of seepage waters percolating to the cave. This shift would be recorded in the speleothem $\delta^{18} \mathrm{O}$ values because the isotopic composition of cave dripwaters in this region reflect the average annual isotopic composition of the precipitation above the cave (Pace-Graczyk, unpublished data, 2007).

[6] For speleothems to record the isotopic signal of rainfall requires several conditions to be fulfilled: 1) rapid flow rates of percolation waters; and 2) equilibrium deposition of the speleothem with its ambient waters. The first condition has been shown to exist for the Briar's Cave [Florea, 2006] where cave drips responded within two months to surface recharge events. Such rapid flow-through times suggest little mixing occurs to the precipitation isotopes upon passage though the bedrock. Sandy soils of the Candler Series above the cave promote very rapid soil infiltration [Thomas et al., 1979] thereby reducing fractionation of percolation waters by evaporation at the surface. Very similar isotopic composition between rainfall and groundwater for the region also indicates rapid infiltration and little fractionation caused by evapotranspiration [Katz, 1998].

[7] The second condition of isotopic equilibrium of calcite deposition, necessary for meaningful interpretation of speleothem isotopes, can be tested by collecting calcite along two growth layers and analyzing their $\delta^{18} \mathrm{O}$ and $\delta^{13} \mathrm{C}$ composition [Hendy, 1971]. Isotopic disequilibria would require 1) enrichment in the ${ }^{18} \mathrm{O}$ with distance from the apex of the calcite layer; and 2) $>0.8 \%$ variation in the $\delta^{18} \mathrm{O}$ along the growth layer [Gascoyne, 1992; Lauritzen and Onac, 1999]. Neither condition occurs for Briars04-02
(Figure S1) and isotopic equilibrium of calcite deposition can be assumed. A second test for equilibrium deposition is whether two speleothems from different caves in the same region possess the same isotopic signal. BRC03-02 (Brown Rat Cave $50 \mathrm{~km}$ south of Briars Cave) does indeed have a very similar isotopic curve, suggesting BRIARS04-02 meets all the necessary criteria (Figure 1b). It should be noted that BRC03-02's isotopic values do not have the range of BRIARS04-02 because of mixing of seepage waters which results in dampening of the isotopic signal of the precipitation.

\section{Causes of Seasonal Shifts in Precipitation in Florida}

[8] Shifts in the seasonal distribution of precipitation in Florida are a result of changing phases in the NAO, ENSO and PDO. These three influences have their most profound effect in the winter season, whereby a negative NAO, positive PDO and El Niño conditions enhance winter precipitation amounts [Hagemeyer, 2006]. To determine if these relationships are occurring at Briars Cave, the winter proportion of total precipitation (\%) was compared to proxies for the NAO [Cook et al., 2002], ENSO (Niño3 region reconstruction) [D'Arrigo et al., 2005] and the PDO [MacDonald and Case, 2005]. Proxies were used for these comparisons so as to keep the same representations of NAO, ENSO and PDO for the later speleothem $\delta^{18} \mathrm{O}$ data comparisons. Precipitation data from Ocala, Florida, was used as this is the closest weather station to Briars Cave.

[9] A negative NAO appears to correspond with an increase in the winter proportion of precipitation (Figure 2a). Only during the last 20 years has this relationship shown any signs of deviation. Niño3 also matches the changes in seasonal precipitation, although surprisingly La Niña conditions correspond to relatively more winter rainfall (Figure 2b). This somewhat contradicts the assertion that El Niño conditions produce more winter precipitation [Hagemeyer, 2006]. However, the same author did find that the strongest La Niña of the last 50 years coincided with actual rainfall $75 \%$ greater than what was predicted. Additionally, Hagemeyer [2006] did not recognize the seasonal differences in precipitation for different regions of Florida. Briars Cave sits close to a transitional boundary between a winter wet season of Florida's panhandle and a summer wet season for the lower half of the peninsula.

[10] The PDO shows correspondence with winter precipitation not on a yearly basis but through its decadal influence whereby the winter proportion of total precipitation matches the 60 year oscillation of the PDO (Figure 2c). There is a noticeable decrease in the winter's contribution to total annual precipitation during the period of 1945-1970, which matches the PDO cool phase.

\section{Seasonal Shifts as Recorded in the Speleothem}

[11] From the above discussion it is clear that there are seasonal changes in the distribution of precipitation in central Florida which are driven by the phase changes in the North Atlantic (NAO) and Pacific Oceans (PDO and ENSO). Additionally, as the isotopic composition of cave dripwaters reflects that of the annual average precipitation 
a

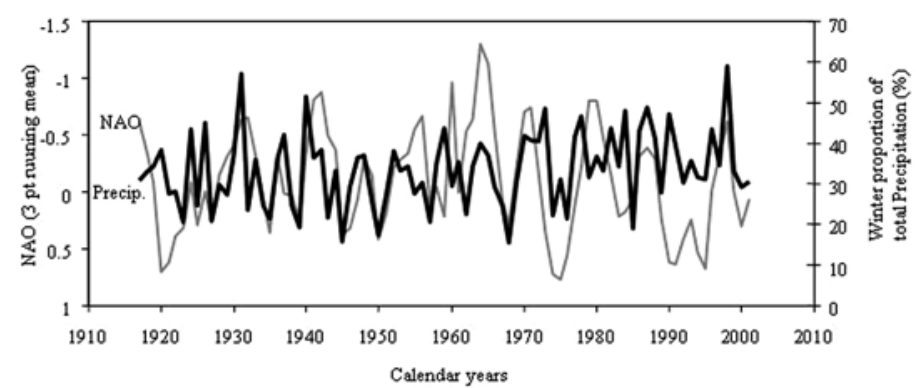

$\mathrm{b}$

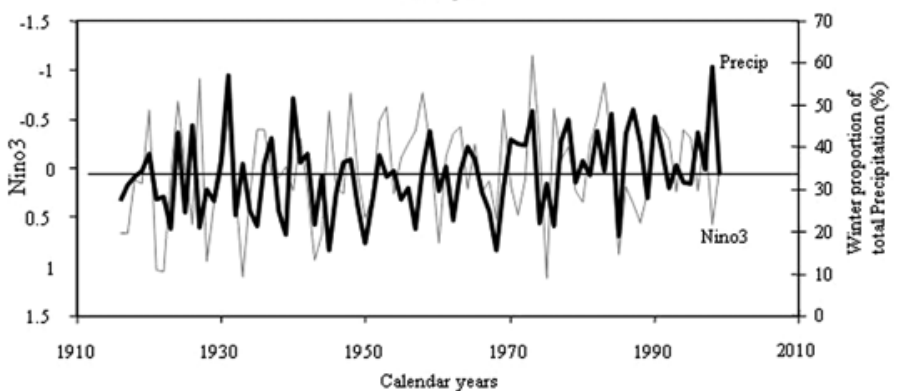

C

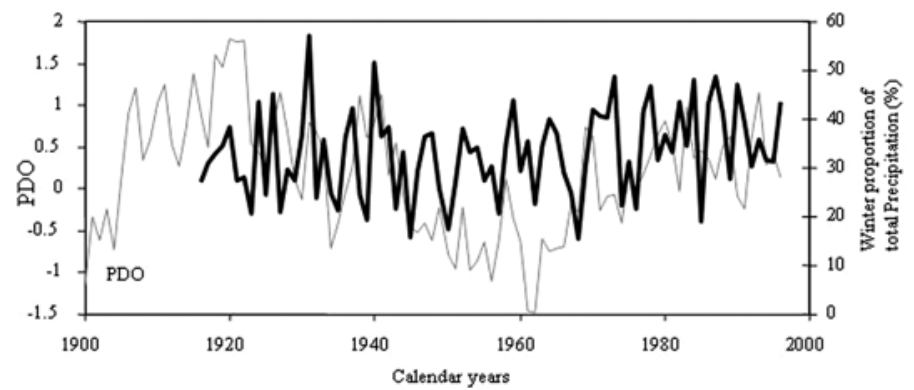

Figure 2. Comparison of winter proportion of total annual precipitation for Ocala, Fl with (a) North Atlantic Oscillation index [Cook et al., 2004], (b) El Niño Southern Oscillation (Niño3 Index) [D’Arrigo et al., 2003], and (c) Pacific Decadal Oscillation (index from MacDonald and Case [2005]).

(Pace-Graczyk, unpublished data, 2007), then these seasonal changes in precipitation distribution should be recorded in the speleothems deposited from these dripwaters. A shift towards more winter precipitation would produce higher isotopic values in the speleothem.

[12] To test the validity of the above supposition, speleothem $\delta^{18} \mathrm{O}$ values from Briars Cave were compared to longest available reconstructions of the NAO, ENSO and PDO. For consistency, these are the same indices used in the above section. When the NAO reconstruction [Cook et al., 2002] is compared to the stalagmite $\delta^{18} \mathrm{O}$ values (Figure 3a), there is a clear synchrony of the amplitude changes in the speleothem with those of the NAO $(r=0.4, p<0.0001)$. As mentioned earlier, winter precipitation has enriched in ${ }^{18} \mathrm{O}$ and strong negative NAO conditions would shift the seasonal distribution of precipitation in central Florida towards the winter. It has been suggested that this increase in precipitation is due to increased lift in the low and mid levels of the atmosphere in response to an increased number of upper level disturbances [NOAA, 2003].

[13] The influence of the El Niño (positive values)/La Niña (negative values) (Niño3 region reconstruction) [D'Arrigo et al., 2005] on Florida precipitation and consequently the stalagmite $\delta^{18} \mathrm{O}$ values (Figure $3 \mathrm{~b}$ ), is not as apparent as with the NAO $(\mathrm{r}=0.06, \mathrm{p}=0.54)$. However, there do appear to be many intervals when the speleothem record and
Niño3 coincide. This result highlights the complexity of the influence of ENSO on Florida's rainfall [Hagemeyer, 2006]. For example, the strongest La Niña event (1988-1989) did not produce the driest winter for Florida in the last 50 years [Hagemeyer, 2006]. Such results would help explain the lack of correspondence between the extremes in both records.

[14] During the last century, the PDO's warm phase resulted in an increase in the winter proportion of total precipitation (Figure 2c). This relationship appears to hold for the last 1,000 years (Figure 3c) where there is a fairly consistent correspondence between the PDO warm phase and higher speleothem isotopic values. Periods of major deviation between the records centered on 75, 450, 580 years coincide with fairly neutral periods in the NAO and ENSO (Figure 2).

\section{Variable Influence of Teleconnections}

[15] Teleconnections between subtropical North America and the Atlantic (NAO) are evident with a negative NAO leading to changing precipitation conditions in Florida, a pattern that appears both robust and persistent for the last millennia as shown in the stalagmite record. This relationship is due to the variable strength of the Atlantic Subtropical High, an essential component of the NAO, and its affect on 

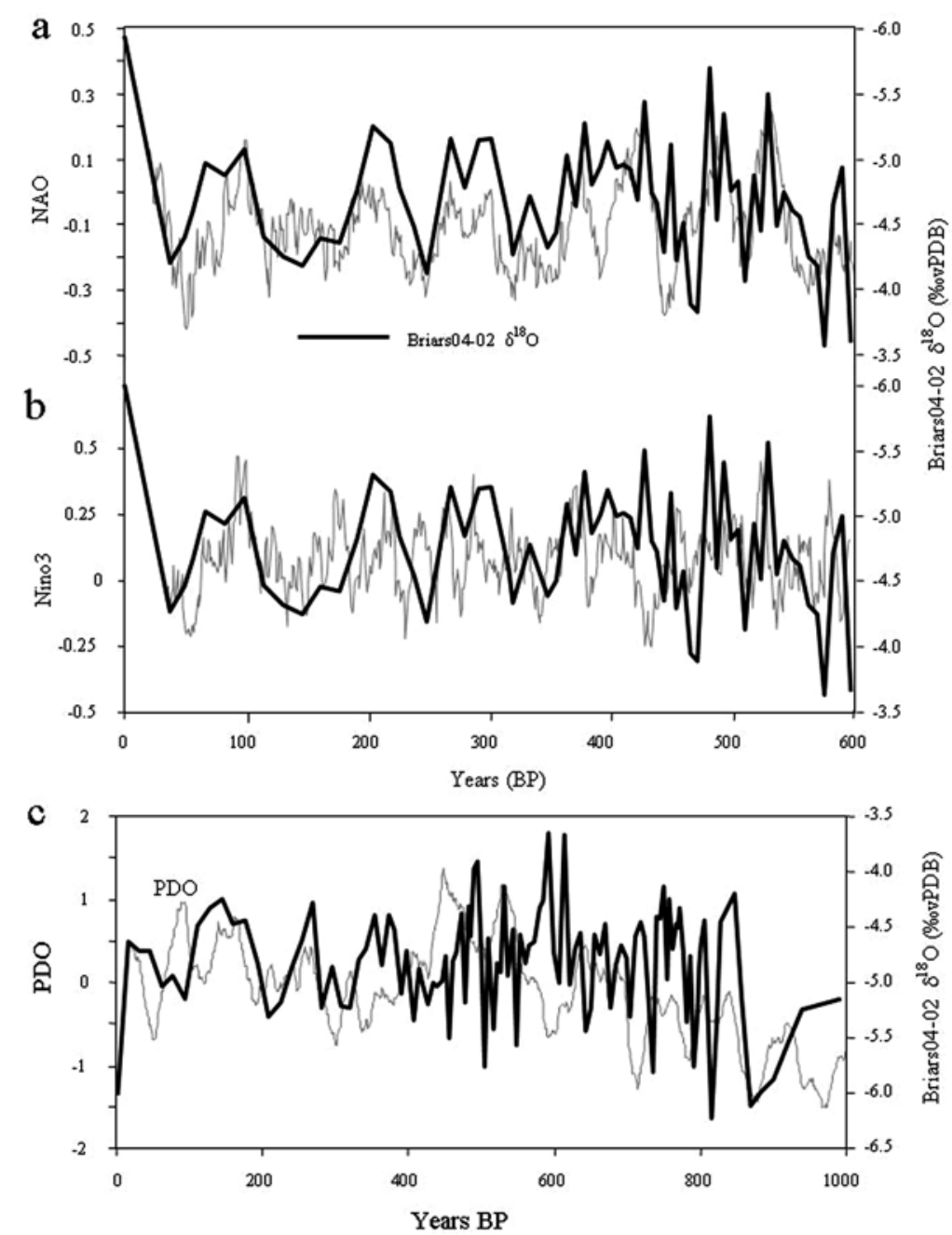

Figure 3. Influence of the variable strength of (a) NAO, as measured by Cook et al. [2002], (b) ENSO recreated using Niño3 index [D'Arrigo et al., 2003], and (c) PDO as measured by MacDonald and Case [2005] on the BRIARS04-02 $\delta^{18} \mathrm{O}$ record.

the passage of cold fronts over Florida during the winter [Hardy and Henderson, 2003]. These findings only partially support prior evidence that highest rainfall amounts occurred during strong El Niño and negative NAO [Hagemeyer, 2006]. The short period of analysis of Hagemeyer [2006], 1950-2000, may have over-emphasized the importance of ENSO for central Florida's precipitation and La Niña conditions do not guarantee dry conditions in Florida. Evidence exists that ENSO variability weakened during the last several hundred years of the Little Ice Age [Gergis et al., 2006], which could explain the lack of correlation.

[16] Although the ENSO teleconnection with subtropical Florida may be weak for the last 600 years, the other Pacific teleconnection, the PDO, does appear to have some influence on the region. Most notably, there is a shift in both records from more negative values (cooler North Pacific, lower speleothem $\delta^{18} \mathrm{O}$ values) from $850-1000$ years ago to higher values from 400-600 years ago. The connection between the PDO and ENSO are well known, where both must possess the same phase for climate anomalies to occur [Gershunov and Barnett, 1998; McCabe and Dettinger, 1999]. This would explain the deviations between the
PDO and the speleothem record where it was noted above that these deviations occurred during periods of neutral ENSO. Such a result has implications for the variable influences of the teleconnections, whereby the NAO seems to be robust and persistent and the Pacific influence (ENSO and PDO) is less so due to the variable shifting of the "phases" of ENSO and PDO.

\section{Conclusions}

[17] The isotopes from Briar's Cave speleothem record seasonal shifts in precipitation with higher values corresponding to a greater winter share of the total annual precipitation. Such shifts in seasonal precipitation appear to be caused by persistent extra-tropical (NAO, PDO) and tropical (ENSO) teleconnections. Such persistence is found through the correlation between changing isotopic composition of rainfall feeding the stalagmite, the changing phase of the NAO and to a lesser extent the PDO. The NAO's consistent influence on the region's rainfall over the last 600 years is a function of the closer proximity of Florida to the Atlantic Subtropical High. Persistence of NAO's influence compared to ENSO for this region climate adds to the 
debate of the relative importance of the high latitude verses tropical controls on long term climate change with our results indicating the former is more influential. However, the irregular oscillation of the NAO compared to the somewhat more predictable ENSO make long-term forecasting of rainfall variability in Florida problematic.

[18] Acknowledgments. This work was funded by a New Researcher Grant from the University of South Florida. We appreciate the thoughtful comments of Joyce Lundberg and the other anonymous reviewers in improving this manuscript.

\section{References}

Burns, S. J., D. Fleitmann, M. Mudelsee, U. Neff, A. Matter, and A. Mangini (2002), A 780-year annually resolved record of Indian Ocean monsoon precipitation from a speleothem from south Oman, J. Geophys. Res., 107(D20), 4434, doi:10.1029/2001JD001281.

Cook, E. R., R. D. D’Arrigo, and M. E. Mann (2002), A well-verified, multiproxy reconstruction of the winter North Atlantic Oscillation index since A. D. 1400, J. Clim., 15, 1754-1764.

D'Arrigo, R., E. R. Cook, R. J. Wilson, R. Allan, and M. E. Mann (2005), On the variability of ENSO over the past six centuries, Geophys. Res. Lett., 32, L03711, doi:10.1029/2004GL022055.

Dorale, J. A., L. A. González, M. K. Reagan, D. A. Pickett, M. T. Murrell, and R. G. Baker (1992), A high-resolution record of Holocene climate change in speleothem calcite from cold water cave, northeast Iowa, Science, 258, 1626-1630.

Enfield, D. B., A. M. Mestas-Nuñez, and J. Trimble (2001), The Atlantic multidecadal oscillation and its relation to rainfall and river flows in the continental U.S., Geophys. Res. Lett., 28, 277-280.

Fleitmann, D., S. J. Burns, M. Mudelsee, U. Neff, J. Kramers, A. Mangini, and A. Matter (2003), Holocene forcing of the Indian monsoon recorded in a stalagmite from southern Oman, Science, 300, 1737-1739.

Florea, L. (2006), The karst of west-central Florida, Ph.D. thesis, 180 pp., Univ. of S. Fla., Tampa.

Gascoyne, M. (1992), Palaeoclimatic determination from cave calcite deposits, Quat. Sci. Rev., 11, 609-632.

Gergis, J., K. Braganza, A. Fowler, S. Mooney, and J. Risbey (2006), Reconstructing El Niño-Southern Oscillation (ENSO) from highresolution palaeoarchives, J. Quat. Sci., 21, 707-722.

Gershunov, A., and T. P. Barnett (1998), Interdecadal modulation of ENSO teleconnections, Bull. Am. Meteorol. Soc., 79, 2715-2726.

Hagemeyer, B. C. (2006), ENSO, PNA and NAO scenarios for extreme storminess, rainfall and temperature variability during the Florida dry season, paper presented at 18th Conference on Climate Variability and Change, Am. Meteorol. Soc., Atlanta, Ga.

Hardy, J. W., and K. K. Henderson (2003), Cold front variability in the southern United States and the influence of atmospheric teleconnection patterns, Phys. Geogr., 24, 120-137.

Hendy, C. H. (1971), The isotopic geochemistry of speleothems-I. The calculation of the effects of different modes of formation on the isotopic composition of speleothems and their applicability as paleoclimate indicators, Geochim. Cosmochim. Acta, 35, 801-824.

Katz, B. G. (1998), Using $\delta^{18} \mathrm{O}$ and $\delta \mathrm{D}$ to quantify ground-water/surface water interactions in karst systems in Florida, paper presented at National Water Quality Monitoring Council Conference, Natl. Water Quality Monit. Counc., Reno, Nev., July.

Lachniet, M. S., S. J. Burns, D. R. Piperno, Y. Asmerom, V. J. Polyak, C. M. Moy, and K. Christenson (2004), A 1500-year El Niño/Southern Oscillation and rainfall history for the Isthmus of Panama from speleothem calcite, J. Geophys. Res., 109, D20117, doi:10.1029/2004JD004694.

Lauritzen, S. E., and B. P. Onac (1999), Isotopic stratigraphy of a last interglacial stalagmite from northwestern Romania: Correlation with the deep-sea record and northern-latitude speleothem, J. Cave Karst Stud., 9(6), 659-669.

Li, W.-X., J. Lundberg, A. P. Dickin, D. C. Ford, H. P. Schwarcz, R. McNutt, and D. Williams (1989), High-precision mass-spectrometric uraniumseries dating of cave deposits and implications for palaeoclimatic studies, Nature, 339, 524-536.

MacDonald, G. M., and R. A. Case (2005), Variations in the Pacific Decadal Oscillation over the past millennium, Geophys. Res. Lett., 32, L08703, doi:10.1029/2005GL022478.

McCabe, G. J., and M. D. Dettinger (1999), Decadal variations in the strength of ENSO teleconnections with precipitation in the western United States, Int. J. Climatol., 19, 1399-1410.

NOAA (2003), Why has it been so wet?, Suncoast Weather Quarterly, 8, 1. Polyak, J., J. B. Rasmussen, and Y. Asmerom (2004), Prolonged wet period in the southwestern United States through the Younger Dryas, Geology, $32,5-8$.

Sacks, L. A. (2002), Estimating ground-water inflow to lakes in central Florida using the isotope mass-balance approach, U.S. Geol. Surv. Water Resour. Invest. Rep. 02-4192, $47 \mathrm{pp}$.

Thomas, B. P., L. Law, and D. L. Stankey (1979), Soil survey of Marion County area, Florida, pp. 25-26, U.S. Dep. of Agric., Tallahassee, Fla.

Y. Asmerom and V. Polyak, Department of Earth and Planetary Sciences, University of New Mexico, Albuquerque, NM 87131, USA.

J. S. Polk and P. E. van Beynen, Department of Geography, University of South Florida, Tampa, FL 33620, USA. (vanbeyne@cas.usf.edu)

L. Soto, Department of Geology, University of South Florida, Tampa, FL 33620 , USA. 